Int. J. Electrochem. Sci., 15 (2020) 8913 - 8927

International Journal of

ELECTROCHEMICAL

SCIENCE

WWW.electrochemsci.org

\title{
Label-free Lectin Impedimetric Biosensor Based on a Polyaniline/Graphene Nanocomposite for the Detection of Escherichia coli
}

\author{
Haiying Yang*, Jianfang Qin, Meng Zhang, Huiyan Shen, Jia Feng, Haoyong Hao \\ Department of Chemistry, Yuncheng University, Yuncheng, 044300, PR China \\ *E-mail: haiyingyang79@ @otmail.com
}

doi: $10.20964 / 2020.09 .34$

Received: 8 April 2020 / Accepted: 25 June 2020 / Published: 10 August 2020

\begin{abstract}
This work reports a label-free impedimetric biosensor based on a polyaniline (PANI) and graphene (G) composite on a glassy carbon electrode (GCE) for the detection of Escherichia coli (E. coli) with lectin as the recognition molecule. The PANI/G nanocomposite was synthesized by in situ electrochemical oxidative polymerization of aniline onto $G$ and Nafion. The effect of the polymerization on the electron performance of the sensing surface was checked. The results indicated that the heterogeneous electron transfer rate increased from $4.30 \times 10^{-4} \mathrm{~cm} \mathrm{~s}^{-1}$ to $4.70 \times 10^{-4} \mathrm{~cm} \mathrm{~s}^{-1}$ after the incorporation of PANI onto the G/Nafion/GCE with ferrous/ferric as the redox probe. The lectin of Concanavalin A (Con A) was used to recognize the carbohydrate moiety on the surface of $E$. coli, which demonstrated the recognition ability of the synthesis interface. The DH5 $\alpha$ E. coli bacteria strain was chosen as a model target. When the biosensor was incubated with the target under optimized experimental conditions, the electron transfer resistance $\left(R_{\mathrm{et}}\right)$ increased when the $E$. coli concentration increased from $5.0 \times 10^{1}$ cells $/ \mathrm{mL}$ to $1.0 \times 10^{4}$ cells $/ \mathrm{mL}$. The detection limit for the biosensor was calculated to be 43 cells $/ \mathrm{mL}$ based on a signal-to-noise ratio of 3 . The biosensor was also challenged by incubation with two different bacteria without Con A binding sites, which showed negligible changes in the $R_{\mathrm{et}}$ value. The hybrid PANI and G nanocomposite enables us to enhance the biosensor response and reproducibility without sacrificing the electrical conductivity, as found for the use of additives. The developed biosensor highlights a promising approach for the sensitive determination of other desired bacteria via incorporation with a nanocomposite.
\end{abstract}

Keywords: impedimetric biosensor; electrochemical polymerization, polyaniline and graphene; lectin; Escherichia coli 
(C) 2020 The Authors. Published by ESG (www.electrochemsci.org). This article is an open access article distributed under the terms and conditions of the Creative Commons Attribution license (http://creativecommons.org/licenses/by/4.0/). 